\title{
Using Debate in EFL Classes
}

\author{
Ali Alasmari ${ }^{1} \&$ Sayed Salahuddin Ahmed ${ }^{1}$ \\ ${ }^{1}$ College of Arts and Sciences, King Khalid University, Kingdom of Saudi Arabia \\ Correspondence: Sayed Salahuddin Ahmed, Department of English, College of Arts and Sciences, King Khalid \\ University, P.O.Box 900, Zip Code 61913, Mohayel Assir, Kingdom of Saudi Arabia. Tel: 966-053-225-5706. \\ E-mail: salahuddin_ju@yahoo.com
}

\author{
Received: October 19, 2012 Accepted: November 26, 2012 Online Published: December 12, 2012 \\ doi:10.5539/elt.v6n1p147 URL: http://dx.doi.org/10.5539/elt.v6n1p147
}

\begin{abstract}
The countries that use English as a foreign language need effective activities which propel students to practice skills of the language properly inside as well as outside classrooms. Debating is a practice that inspires learners to open their mouth, get into discussion, defend their own positions, place counter arguments and also conduct research on related issues. While debating in English, the debaters get involved into a challenging and thrilling activity; moreover, they find themselves well-conversant in the aforesaid language. This paper presents the rationale behind using debate in EFL classes and proposes a few modules of debating which, if practiced properly, will make students confident users of English language in academic, social and professional settings. The paper also examines utilities of the modules and exhibits how students while practicing debate can improve their English language as well as presentation skills. The modules can be practiced in EFL classes, English language centers, debating clubs or other formal and informal settings where teaching-learning of English language is concerned.
\end{abstract}

Keywords: EFL, debate, skills, communication, learning, motivation

\section{Introduction}

Debating is a formal method of interactive and representational argument (Debate, n.d.) aimed at persuading judges and audience. It is a rhetoric practice in which different strategies of logic building as well as delivery are used to pull in the target audience to a conclusion on a controversial issue. Debating can be used in EFL classes as a tool to make students practice skills of English language in real-life situations. Krieger (2005) comments:

Debate is an excellent activity for language learning because it engages students in a variety of cognitive and linguistic ways. In addition to providing meaningful listening, speaking and writing practice, debate is also highly effective for developing argumentation skills for persuasive speech and writing. (p. 25)

Timothy Stewart (2003) found that 75 per cent of his unmotivated and reserved students ranked debate as their most favorite classroom activity. A survey conducted on non-native English speakers in U.S. universities about the language needs found that formal speaking and listening comprehension skills were their two biggest problem areas (Ferris, 1998). Debate offers English language teachers a way to combine practices of these important skills. Quoting Davidson (1995), Krieger (2005) said that with practice, many students had obvious progress in their ability to express and defend ideas in debate [and] they often quickly recognized the flaws in each other's arguments. Nisbett (2003) states: "Debate is an important educational tool for learning analytic thinking skills and for forcing self-conscious reflection on the validity of one's ideas (p. 210)." Fukuda (2003), in a study conducted with Japanese students, found that before the practice of debate only 30.8 per cent of the students were not afraid of expressing their opinions. After the debate, this figure rose to 56.7 per cent. He added that the knowledge and skills which came from the practice of debate led students to become more accustomed to expressing opinions.

Students need to perform various academic tasks in different disciplines. Academic language has been defined as "the language that is used by teachers and students for the purpose of acquiring new knowledge and skills" (Chamot \& O'Malley, 1994, p. 40). Chamot and O'Malley listed a number of language functions that are needed in all content areas: explaining, informing, justifying, debating, describing, classifying, proving, persuading, and evaluating. In addition, students are often expected to state, discuss, question, and defend opinions. Students, preparing for a debate practice many of these language functions. Pally (2000) claims: "[C]ritical thinking 
skills_-including questioning information ... are used widely in academic/professional settings" (p. 4).

When debating is used in EFL classes, all four skills of English language (e.g. listening, speaking, reading, and writing) are practiced. Moreover, debaters need to master pronunciation of words, stress, vocabulary, brainstorming, script writing, logic building, argumentation and refutation. So practicing debate in English requires many skills which ultimately lead them to learn English.

In an EFL setting, where learners have inadequate opportunities for practicing English in real-life situations, debating opens up opportunities for them to use the language in the form of expressing their opinions with logic. This is a single practice where students need to use all English skills along with skills in delivery, presentation and vocabulary building. Makiko Ebata (2009) puts it:

When learning a new language for global communication, students are required to confidently express their thoughts. In order for students to be vocal, critical thinking skills are essential. The use of debate has been an effective technique for strengthening my students'speaking and critical thinking abilities. (p. 35)

English language teachers and practitioners have already proved debating as an effective tool in teaching English which is a strong source of motivation for EFL teachers who are yet to use debate in their classes.

\section{Functions of Debating}

Debating in English is a practice that requires all English language skills along with the skills of presentation and delivery. Debaters need updated information about current issues and concepts of different fields. Moreover, they need to conduct research on various issues. While presenting their logic and argument, debaters require standard delivery skills to convince judges and audiences. When practiced in an EFL class, debating makes students use language and presentation skills. The discussion that follows dwells on the utility of debating in learning the skills of English language.

\subsection{Ice Breaking}

Debating helps in several ways to ice-break in EFL classes. Sometimes, especially in the first classes where students are very often found anxious about using English language, ice breaking turns to be very difficult for teachers. In such classes, students are found reluctant to speak in English. Sometimes, in the very first class, teachers ask students to come in front of the classroom and speak which rather increases students' fear and they grow hatred towards English. But if teachers introduce simple but controversial topics to the class and ask them to comment on those topics while sitting in their respective seats, students will feel encouraged to take part in discussion. Eventually, they will be encouraged to speak in English. Teacher's role should be encouraging as well as motivating.

\subsection{Listening}

Through practicing debate, students can improve their listening skills. By using listening aids like radio, tape recorder, $\mathrm{CD}$ player and $\mathrm{PC}$, learners will listen to audio clips e.g. conversation, speech, debate, talk shows and reports. They will watch video clips of debate sessions, speeches of famous speakers, talk shows, round table discussions, reports, and news. Recorded video clips of debate sessions, news, reports as well as talk shows on television channels like BBC and CNN can be very good resources for practicing listening in English. Learners will listen to CDs of different dictionaries to repair pronunciation of sounds and words. They will also watch selected English movies in the classroom which will be followed by group discussion. Teachers will give feedback on the discussion. In the feedback, teachers should focus on sounds, pronunciation, accent as well as use of words, technical words and jargons. In this case, teachers can use their notes on students' difficulty in pronouncing particular sounds and words.

\subsection{Speaking}

Debating can be used brilliantly to boost up students' speaking in English. Practices can be organized in various ways. A few of them have been discussed in this paper. In many EFL settings, students are found scared of speaking in English when they take admission into universities. In most of the cases, their poor background knowledge and practice in English are responsible for this. Use of debate, speech and conversation in EFL classes will first of all drive out students' fear about English language. Moreover, regular practice of debate, speech and conversation will improve their fluency, pronunciation and vocabulary. They will also be familiar with jargons and technical terms as debating covers a variety of areas and issues. Teachers will work as moderators and will facilitate students' learning. They will provide feedback on speeches with focus on delivery more particularly on gesture, posture, pronunciation, accent, intonation, stress, vocabulary, choice of words; data and information; relevancy of the information and logic building. Thus while practicing debate, speech and 
conversation in the class, students will practice many skills, learn many new words and collect information about many areas which all together will enrich their spoken English and ultimately make them confident speakers.

\subsection{Reading}

Debating requires knowledge of many interrelated disciplines and areas which entails extensive study of current issues as well as social, economic and political theories and concepts. Studies into these disciplines enrich students' level of knowledge, enhance their reading habit and develop their vocabulary. If debate topics are announced earlier, students can collect information and discuss in groups. Thus, in the pretext of preparing for debating, students develop reading habit. Debating clubs organize study circles to discuss topics and theories that are relevant with debating. Students use many sources to gather data and information. Teachers also introduce them to different sources of information e.g. local and international newspapers, magazines, books and websites. Students can collect information and make wall-magazines based on different issues and occasions. Through these practices, students prepare themselves for taking part in debating.

\subsection{Writing}

Practice of debating develops learners' writing skills too. While writing debate scripts, students practice writing composition in an organized way. To make debate scripts, they need to brainstorm on the topics and jot down points. Thus, they learn how to think about a topic in a systematic manner and also to link between points. Moreover, they learn the process of prioritizing the points. If students get debate topics one or two days earlier, they usually collect information and write the whole script. Debate-scripts are like argumentative essays. Thus they learn writing argumentative paragraphs and essays. Furthermore, students practice limiting topics and making them controversial enough for arguments and counter-arguments. When students make the final debate-script, they retain only the main points, not the details. In this way, they master limiting topics, writing topic sentences and also making outlines. To sum up, debating entices students to write composition in English.

\section{Debate Modules}

Good forms of debate incorporate a high level interaction among students where they present and support arguments, question or rebut arguments and finally make an appeal or summary. The modules discussed below can be used to practice debate in EFL classes.

\subsection{Module 1}

Practice: Teacher will provide students with controversial topics. Next class every student will bring five points for and five points against their respective topics. Teacher will pick one student to place his points to the class. The teacher will then pick another student and ask him whether he agrees with his classmate's points. The second student will explain with logic, data and information why he agrees or disagrees with his classmate.

Utility: This practice will break ice and students will feel motivated to speak in English. Teachers can introduce this activity in the first class. It will remove students' shyness and motivate them to speak in English. Teacher will note down learners' areas of improvement and give feedback.

\subsection{Module 2}

Practice: Students will choose from a pool of topics (selected by teacher), take 5 minutes to brainstorm and make brief outlines. Then they will speak extemporary.

Utility: Through this practice, students will learn to speak extemporarily. They will also acquire the techniques to brainstorm on a topic which will improve both speaking and writing skills.

\subsection{Module 3}

Practice: Teacher will form debate teams each with 3-5 students and select topics for them. Team positions to the topics will be given through lottery. Topics and positions should be provided just 30-45 minutes before the debate sessions start. Teacher will act as moderator while other students will play the role of audience.

Utility: Students will learn to work in a group to research, discuss and build cases together. They will also apprehend how to divide the points among themselves and follow team strategies. Through practicing debating, students will learn the skills of English language and the art of interpersonal relationship.

\subsection{Module 4}

Practice: Teacher will introduce a topic to the class and invite students to place their respective opinions. Students will speak for or against the topic. Teacher will play the role of moderator. 
Utility: Participating in open discussions will help students express themselves in academic, social and professional settings in future. The activity will also encourage them to read extensively about current issues.

\subsection{Module 5}

Practice: Teacher will arrange a roundtable discussion with 10-12 students. Student-discussants will be given topic a few days earlier so they can collect adequate information. Teacher will be the moderator. He will control the conversation and pass floor to students. Other students will play the roles of journalists and audiences. At the end of the session, they'll ask questions to the discussants.

Utility: In this activity, students will play the role of several professionals. This may be more effective with senior or outgoing students who will be exposed to various jobs in near future. Students will go through extensive reading in order to use data and information in their speeches. They will also learn to support, contradict and extend others' views. The students playing the roles of journalists will learn the strategies of listening with attention and taking notes. Moreover, they will learn how to make effective and strategic questions.

\subsection{Module 6}

Practice: Teachers and students will arrange formal debate sessions on various issues like campus development, freedom of speech, professional advancement, environmental pollutions, climate change, adverse effects of modern marketing policies, role of advertisement, economic instability, education crisis, exploitation of women and world peace. They will arrange debate sessions on different occasions like birth days of poets, authors, great leaders, theoreticians; national and international days, as International Women's Day, Valentine's Day, International Mother Language Day, International Labor Day; current issues e.g. Earthquake in Japan, US election; local issues as social, political, educational and environmental crises of the country. For example, on the birth day of William Shakespeare, English department of Jahangirnagar University in Bangladesh arranged a debate on the topic "There is no peer of Shakespeare." One teacher defended Shakespeare, while the other one placed Christopher Marlowe in his place. The session was both informative and enjoyable.

Utility: Students will practice techniques of debating and skills of English language. If the debate sessions are arranged among universities, debaters' confidence will increase by facing unknown opponents. As debate sessions are based on concepts and current issues, they need to go through an extensive reading on relevant concepts, theories and issues. Thus their reading skill will improve and they will be familiar with research strategies.

\subsection{Module 7}

Practice: Students can practice fun debate on interesting topics. This kind of debate will be entertaining as well as informative. Fun debate sessions may be organized on many issues and occasions which are basically extemporary in nature.

Utility: Fun debates will give debaters some relaxation as they are always busy with debating on serious topics that require deep thinking and comprehensive knowledge. Moreover, fun debate will bring more students to debating.

\subsection{Module 8}

Practice: Teacher will write a few topics on the board and ask students to limit in order to make them controversial or debatable. Students will then be asked to write topic sentences and to make short outlines which will work as debate-script outlines.

Utility: Students will learn limiting topics, making outlines and writing topic sentences which are very effective strategies for both speaking and writing.

\subsection{Module 9}

Practice: Teacher will select topics, form teams and decide positions of teams on the topics. Students will write short compositions in support of their respective positions. They will use necessary logic, data and information to make a wall magazine; they'll also use necessary photos, pictures, cartoons and graphs to make the wall magazine more eye-catchy and communicative. Teacher will be the editor of the magazine.

Utility: Making a wall magazine will be an effective effort to learn reading and writing skills. Students will learn both reading and writing skills. While gathering information, students will do research on various issues. In addition, they will practice the strategies for writing composition and creative writing. EFL writing classes or writing centers may organize such projects. 


\subsection{Module 10}

Practice: Teacher and students will watch video clips of debate sessions. After the clips are played, teacher will explain strategic points of the speeches and ask students questions.

Utility: Students' listening in English will be improved. While watching speeches of good debaters, students will learn strategies for case building, arguing, summing up and delivery.

\subsection{Module 11}

Practice: Online debate sessions may be arranged among local and foreign universities on Skype and Yahoo messenger through chatting or sound-text softwares.

Utility: If debate sessions are arranged with students of some universities of native English speaking countries, the target students will improve their speaking and listening in English. Furthermore, learners will be more proficient in using technology.

\subsection{Module 12}

Practice: Students will take part in online forums and post their opinions and views on various issues.

Utility: Learners' reading and writing skills in English will be developed. Moreover, they will master the art of thinking on issues and putting their own ideas with logic.

\subsection{Module 13}

Practice: E-mail, "the mother of all Internet applications" (Warschauer, Shetzer, and Meloni, 2000, p. 3) can be used as an effective tool for students to argue on various issues. Oxford (1990) writes, "(online debating) can be a medium of real communication in the target language, including composing and exchanging messages with other students in the classroom or around the world" (p. 79).

Utility: While communicating and exchanging opinions through emailing with other students at home and abroad, the target learners will get a broader domain to dwell in. It will improve their writing and vocabulary. It will also expose them to a larger environment. Moreover, they will be familiar with other cultures.

\section{Conclusion}

The countries where English language is treated as a foreign language are laden with many problems that prevent students from using the language outside classroom. Moreover, in most of the cases, EFL teachers fail to implement properly the best methods, approaches and classroom activities to teach students the skills of English language. In such cases, students in these countries need to go through some practices that make them practice English language in real-life situations. Debating can be used to learn English in both formal and informal settings. It is such an activity that engages learners in practicing all skills of English language. If the debate practice modules are practiced appropriately, students will learn both English language and presentation skills which will make them confident users of English language in academic, social and professional settings.

\section{References}

Chamot, A. U., \& O’Malley, J. M. (1994). The CALLA handbook. New York: Addison-Wesley.

Davidson, Bruce. (1995). Critical thinking education faces the challenge of Japan. Inquiry: Critical Thinking Across the Disciplines, 17(3), 33-42.

Debate. (n.d.). Retrieved from http://en.wikipedia.org/wiki/Debate

Ebada, Makikio. (2009). Effectiveness of debate in EFL classes. Japan: JALT Publications.

Ferris, D. (1998). Students' views of academic aural/oral skills: A comparative needs analysis. TESOL Quarterly, 32, 289-318. http://dx.doi.org/10.2307/3587585

Fukuda, Shinji. (2003). Attitudes toward argumentation in college EFL classes in Japan. Proceedings of the First Asia TEFL International Conference (pp. 417-418). Pusan, Korea.

Krieger, Daniel. (2005). Teaching debate to ESL students: A six-class unit. The Internet TESL Journal, 11(2).

Nesbett, Richard E. (2003). The geography of thought. New York: The Free Press.

Oxford, R. (1990). Language learning strategies. New York: Newbury House.

Pally, M. (2000). Sustaining interest/advancing learning: Sustained content-based instruction in ESL/EFL-Theoretical background and rationale. Sustained content teaching in academic ESL/EFL. Boston: Houghton Mifflin. 
Stewart, Timothy. (2003). Debate for ESOL students. TESOL Journal, 12(1).

Warschauer, M., Shetzer, H., \& Meloni, C. (2000). Internet for English teaching. Alexandria, VA: TESOL Publications.

\section{Authors}

Ali Alasmari is an Assistant Professor of TESOL. His doctorate is in TESOL and Technology from the Ohio State University, Columbus, $\mathrm{OH}$, and his research interests include technology, E-learning, action research, and Quality Assurance in ELT. He is a member of a number of professional and educational associations including TESOL International, TESOL Arabia, GloCALL, etc. He attended and presented in several international conferences such as TESOL International, TESOL Arabia, and GloCALL.

Sayed Salahuddin Ahmed teaches English at King Khalid University in Saudi Arabia. Earlier, he taught English in several universities in Bangladesh. Moreover, he worked as a foreign language instructor at University of Georgia, USA. His areas of interest include teaching English as a foreign language, curriculum and material development, teacher education, ELT management, Business English and American literature. Sayed has published a book and a few articles. He has presented and participated in seminars and workshops in Dhaka, New York and Washington DC. He is a member of TESOL International and Bangladesh English Language Teachers' Association (BELTA). 